\title{
miscellany
}

\section{Burden Research Prize}

The Burden Trust invites applications for the 2001 Burden Research Prize. The prize, which consists of an award of $f 1000$, is open to all registered medical practitioners, the greater part of whose time is spent working in the field of learning disabilities in the UK or the Republic of Ireland. The prize will be awarded for outstanding research work that has either been published, accepted for publication or presented as a paper to a learned society during the 3-year period ending 31 December 2000. An application form and further details may be obtained from Dr Oliver Russell, Norah Fry Research Centre, University of Bristol, 3 Priory Road, Bristol BS8 1TX (Tel.: 0117923 8137).

\section{New Fellows for King's College London}

The Fellowship of King's College London (FKCL) is the most prestigious award the College can bestow. The award of the Fellowship is governed by a statute of the College and reflects distinguished service to the College by a member of staff, conspicuous service to the College or the achievement of distinction by those who were at one time closely associated with the College.

Professor Stuart Checkley, Dean of the Institute of Psychiatry at King's, which under his leadership has achieved top rating for its research, has been awarded the fellowship for 2000. Professor Checkley is also Professor of Psycho-neuroendocrinology and a Fellow of the Royal Colleges of Psychiatrists and Physicians.

\section{Alzheimer Scotland-Action on Dementia}

The Charity Alzheimer Scotland-Action on Dementia has launched its extensive new website: http://www.alzscot.org. The new site holds over 250 pages of information, including a wide range of information for carers, people with dementia and professionals. Information is included about dementia; coping with caring; treatment and research; money and legal matters; local services and public policy. For further information contact Kate Fearnley, Information Officer, Alzheimer Scotland-Action on Dementia on tel. : 0132431453 (day) and 01314440172 (evening).

\section{New Mind website launched}

Mind's new website, designed in partner ship with UKpractice.net, was launched on the 16 August (http://www. mind.org.uk). The site will provide updated mental health information for both the general public and health care professionals. The site will include the text of over 40 information factsheets and nearly 20 Mind booklets, the latest press releases and campaigns, fund-raising events and activities, plus help in finding the nearest local Mind association. For further information contact Sue or Julia in the Mind Press Office on tel. : 0208522 1743.

\section{Royal College of Psychiatrists Golf Society, 2nd Annual Meeting - Friday 7 July 2000}

This year's competition was held at Lundin Golf Club, Fife, in conjunction with the Edinburgh Summer College Meeting. The course provided a rigorous test of links golf and the competition was won, in the face of stiff opposition, by DrTom Brown, Consultant Psychiatrist at St John's Hospital, Livingston. It is proposed that next year's competition will be held during the College Summer Meeting in London at a venue yet to be confirmed. Further details are available from Mr Robert Jackson, Senior Continuing Professional Development Administrator, Postgraduate Educational Services Department, The Royal College of Psychiatrists.

\section{Changing Minds: Every Family in the Land new campaign video now available}

The Changing Minds Campaign is delighted to announce that a 14 minute videotape exploring the origins and nature of mental illness and how it affects us all is now available from the College. Written, directed and narrated by Dr Mark Salter, Consultant Psychiatrist at the Homerton Hospital, this film is an extremely useful tool for those members or their colleagues who may be lecturing or organising events on the stigma of mental illness. Please watch this film, talk about it and then show it to someone else. They say that you can judge a civilisation by the way it treats its mentally ill. If we can learn to 'stop, think and understand', then there may be hope for us yet.

The campaign would like to thank Bristol Myers Squibb Ltd for their generous help in producing this video.

For a free copy of the videotape, contact Liz Cowan in the External Affairs Department (tel. : 02072352351 ext. 122 e-mail: Icowan@rpsych.ac.uk). The Campaign is dependent on external funding and a small donation of $f 5.00$ would be welcome. 